\title{
FEATHER GROWTH RATE AND MASS IN NEARCTIC PASSERINES WITH VARIABLE MIGRATORY BEHAVIOR AND MOLT PATTERN
}

\author{
IVÁn de la Hera, ${ }^{1,2,5}$ David F. DeSante, ${ }^{3}$ and Borja Milá ${ }^{4}$ \\ ${ }^{1}$ Department of Animal Ecology, Netherlands Institute of Ecology (NIOO-KNAW), P.O. Box 50, 6700 AB Wageningen, The Netherlands; \\ ${ }^{2}$ Department of Zoology and Animal Cell Biology, Universidad del País Vasco (UPV-EHU), 01006 Vitoria-Gasteiz, Spain; \\ ${ }^{3}$ Institute for Bird Populations, P.O. Box 1346, Point Reyes Station, California 94956-1346, USA; and \\ ${ }^{4}$ National Museum of Natural Sciences, Spanish Research Council (CSIC), Madrid 28006, Spain
}

\begin{abstract}
Bird species vary greatly in the duration of their annual complete feather molt. However, such variation is not well documented in birds from many biogeographic areas, which restricts our understanding of the diversification of molt strategies. Recent research has revealed that molt duration can be estimated in passerines from ptilochronology-based measurements of the growth rate of their tail feathers. We used this approach to explore how molt duration varied in 98 Nearctic species that have different migratory strategies and molt patterns. As previously documented for Palearctic species, migration was associated with a shortening of molt duration among species that molted during summer on their breeding range. However, molts of winter-molting migratory species were as long as those of summer-molting sedentary species, which suggests that winter molt also allows Nearctic migrants to avoid the temporal constraints experienced during summer. Our results also suggest that migratory species that undergo a stopover molt within the Mexican monsoon region have the shortest molt duration among all Nearctic passerines. Interestingly, and contrary to expectations from a potential tradeoff between molt duration and feather quality, observed variation in feather growth rate was positively correlated with differences in tail feather mass, which may be caused by differences among groups in the availability of resources for molting. We encourage the use of similar approaches to study the variation in molt duration in other geographic areas where knowledge of the evolution of molt is limited. Received 28 September 2011, accepted 12 February 2012.
\end{abstract}

Key words: allometry-isometry, MAPS, PDAP, phylogenetic ANCOVA, scaling relationships.

\section{Tasa de Crecimiento y Masa de las Plumas en Paseriformes Neárticos con Diferente Comportamiento Migratorio y Patrón de Muda}

RESUMEN.-Las aves muestran gran variación entre especies en la duración de su muda completa anual. Sin embargo, dicha variación no está bien documentada en aves de muchas áreas biogeográficas, lo que limita nuestra comprensión sobre la diversificación de sus estrategias de muda. Algunas investigaciones recientes han revelado que la duración de la muda puede ser estimada en paseriformes a partir de medidas de la tasa de crecimiento de las plumas de la cola obtenidas por medio de la técnica conocida como ptilocronología. En este estudio empleamos esta aproximación para explorar la variación en la duración de la muda de 98 especies de aves neárticas que muestran diferentes estrategias migratorias y patrones de muda. Al igual que lo observado previamente en especies de origen paleártico, la migración se asoció con una reducción en la duración de la muda en las especies que mudaron su plumaje durante el verano en sus áreas de cría. Sin embargo, la duración de la muda en los migrantes con muda invernal fue tan larga como la de los sedentarios que mudan durante el verano, lo que sugiere que la muda invernal también permite a los migrantes neárticos evitar las presiones temporales que se experimentan durante el verano. Nuestros resultados también sugieren que las especies migratorias que paran durante su migración otoñal en la región del monzón mexicano para llevar a cabo su muda, presentan la duración de la muda más reducida entre los paseriformes neárticos. De forma interesante, y en contraste con las predicciones sobre la existencia de un compromiso potencial entre la duración de la muda y la calidad de las plumas, la variación observada en la tasa de crecimiento de las plumas estuvo correlacionada positivamente con diferencias en la masa de las plumas de la cola, lo que puede ser causado por diferencias entre grupos de especies en la disponibilidad de recursos para la muda. Finalmente, se propone el uso de aproximaciones similares para estudiar la variación en la duración de la muda en otras áreas geográficas donde el conocimiento sobre la evolución de la muda es todavía limitado.

BIRDS HAVE A limited period during the year when environmental conditions are favorable enough to satisfy the high energetic demands of molting (Barta et al. 2006, 2008). The replacement of old feathers by new ones is a process common to all avian taxa, and it generally takes place once each year, immediately after breeding, to reset the functional properties of plumage (Ginn and Melville 1983, Jenni and Winkler 1994). Growing evidence supports the idea that molts of longer duration allow

${ }^{5}$ E-mail: ivan.delahera@ehu.es

The Auk, Vol. 129, Number 2, pages 222-230. ISSN 0004-8038, electronic ISSN 1938-4254. @ 2012 by The American Ornithologists' Union. All rights reserved. Please direct all requests for permission to photocopy or reproduce article content through the University of California Press's Rights and Permissions website, http://www.ucpressjournals. com/reprintInfo.asp. DOI: 10.1525/auk.2012.11212 
the production of feathers of higher quality than shorter molts (Dawson et al. 2000, Serra 2001, Griggio et al. 2009, de la Hera et al. 2010b, Serra et al. 2010), so selection will tend to maximize the investment of time and energy in feather production. However, the amount of time that can be allocated to molt is expected to be constrained by the temporal requirements of other important activities of the annual cycle with which molt normally does not overlap, such as breeding and migration (de la Hera et al. 2009a, Rohwer et al. 2011).

Within the life history of passerine birds, migratory behavior has been suggested as a main determinant to explain the observed variation in molt duration (Kjellén 1994, de la Hera et al. 2009a) and, eventually, a factor leading to the evolution of different temporal patterns of molt (Svensson and Hedenström 1999, Hall and Tullberg 2004). In temperate regions, nonmigratory species have sufficient time during summer and early autumn to undergo relatively prolonged molts, with the arrival of the winter's environmental deterioration as the only temporal constraint (Barta et al. 2006). However, the scenario is significantly different in migratory species (Barta et al. 2008, Hedenström 2008), for which the time available for molting in summer will be limited by the initiation of autumn migration, causing a reduction of molt duration in migratory species compared with sedentary ones (de la Hera et al. 2009a). Interestingly, some intraspecific studies have shown that a shortening of summer molt duration might be associated with a reduction in the mass and quality of feathers (Dawson et al. 2000, de la Hera et al. 2009b). Although there is no empirical evidence to support the extrapolation of previous patterns to the interspecific level, it has been suggested that the tradeoff between molt speed and feather mass might explain why some long-distance migratory species, which are extremely time-constrained after breeding but can occupy areas with suitable environmental conditions for molting during periods other than summer (Moreau 1972, Barta et al. 2008), have adopted drastic changes in the timing of their annual complete molt (Svensson and Hedenström 1999, Hall and Tullberg 2004, de la Hera et al. 2010b).

A large part of our knowledge of the relationship between migration and molt in passerines comes from the study of Western Palearctic species, for which we have information on molt duration for many species, obtained using a comparable methodology (see Ginn and Melville 1983). However, few data regarding molt duration are available in other biogeographic contexts (Ryder and Wolfe 2009, Bridge 2011), where the ecological pressures acting on birds could be dramatically different, thereby promoting the appearance of molting strategies rarely present in Palearctic species. For example, some Nearctic migrants interrupt their autumn migration to undergo a complete molt in the monsoon region of northwestern Mexico (Rohwer et al. 2005), a strategy defined here as stopover molt. Although some recent research has focused on understanding the ecological and evolutionary significance of this molt pattern (Pyle et al. 2009, Chambers et al. 2011), little is yet known about its advantages and disadvantages in relation to other molting strategies. Consequently, a comparison of molt duration and feather quality among Nearctic species with variable migratory behaviors and molt patterns could promote a more comprehensive understanding of the evolution of stopover molt.

The primary problem in conducting such analyses is the lack of comparable estimates of molt duration for most species. Recent research, however, has revealed that primary molt duration can be estimated from the individual growth rate of a single feather (de la Hera et al. 2011), on which growth rate can be measured by the technique known as ptilochronology (Grubb 2006). In the present study, we used this approach on the outer rectrices of 98 Nearctic passerine species to explore how growth rate varied among five groups of species with variable life-history strategies regarding migratory behavior and molt pattern: sedentary species with summer molt, partially migratory species with summer molt, fully migratory species with summer molt, fully migratory species with stopover molt, and fully migratory species with winter molt. In order to shed additional light on the diversification of molt patterns in Nearctic birds, we also explored the variation in rectrix feather mass and its relationship to feather growth rate among these five groups.

\section{Methods}

Feather samples and measurements.-This study is based on feathers available at the collection hosted at the Conservation Genetics Resource Center (CGRC) of the University of California, Los Angeles. Feathers stored at this institution are supplied by volunteer bird-banders (mainly through the Monitoring Avian Productivity and Survivorship [MAPS] program; DeSante and Kaschube 2009) and by researchers working across North America and other geographic regions, who are encouraged to collect at least one of the outermost tail feathers (rectrix no. 6 according to the centrifugal numeration of the tail; Jenni and Winkler 1994), which allows comparable analyses of feather traits among species. Here, we consider only feathers from species that breed in North America and from individuals that, when sampled, carried tail feathers produced during a molt process that involved all flight feathers (i.e., complete molt; Jenni and Winkler 1994); thus, these feathers are generally from after-second-year individuals only. In making these determinations, we took into account the date of capture of the bird, the age assigned to the bird by the supplier of the sample, and information about the molt of each species obtained from the literature (Pyle 1997, Rohwer et al. 2005). Using this information, we excluded from the study individuals whose tail feathers had been grown during the fledging period (i.e., birds identified as hatching-year and second-year individuals) or during a partial molt process.

In the laboratory, we first measured feather growth rate by means of ptilochronology. This technique is based on the presence of an alternating pattern of light and dark bands perpendicular to the rachis of the feather, where one dark band (produced during the day) plus one light band (produced during the night) corresponds to one day of feather growth and is called a "growth bar" (Brodin 1993). We placed feathers on a black card and marked the length of feather occupied by 10 growth bars (i.e., length of feather synthesized in 10 days; hereafter "feather growth rate"; Grubb 2006) using two entomological pins. After removing the feather from the card, we measured the distance between pins using a digital caliper $(0.01 \mathrm{~mm}$ resolution). It is important to note that feather growth bars are more easily visible on tail feathers than on feathers from other feather tracts, and on postjuvenile feathers than on feathers produced during the fledging period (i.e., juvenile feathers; I. de la Hera pers. obs.). Recent research also shows that ptilochronology-based measurements of growth rate on tail feathers produced during a complete molt process are able to predict 
approximately half of the among-species variation in molt duration, which brings about the possibility of using this index as a proxy for molt speed (de la Hera et al. 2011).

All feathers used in the study were kept together for more than one week, and then the mass of all feathers was measured within two consecutive days using a high-resolution digital balance $(0.1 \mathrm{mg}$ of instrumental repeatability). Although room temperature and humidity were not controlled, we expect that room conditions affected all feathers in a similar way, which would make it unlikely that the large variation in feather mass among species was biased by storage conditions. Feather mass represents the quantity of material invested by individuals in feathers, and it is expected to be associated with the structural complexity and quality of the feather, as has been observed in several intraspecific studies (Dawson et al. 2000, de la Hera et al. 2010a).

Finally, in order to control for the expected variation in feather growth rate and mass caused by interspecific differences in the size of the feathers, we also measured overall feather length (i.e., from the base of the calamus to the tip of the feather) with the aid of a digital caliper. Previous research on primary feathers has stressed the importance of considering the scaling relationships among feather growth rate, feather mass, and feather length to understand the evolution of avian molt (Rohwer et al. 2009a). Our data allowed us to explore such associations within a single tail feather.

All feather measurements were taken by the same person (I. de la Hera) in September 2008 during a short stay at CGRC. We excluded feathers damaged by natural wear or by previous use for DNA extraction, two circumstances that would compromise the reliability of our measurements. In total, we considered 589 individuals belonging to 98 species, with sample size per species ranging from 2 to 10 individuals (see Appendix).

Migratory behavior and molt pattern of Nearctic passerines.-We assigned a migration pattern to each of the 98 species included in our study, following the categorization made by $\mathrm{Al}-$ sop (2001), who distinguished three different groups of species according to their migratory behavior: sedentary, partially migratory, and fully migratory species. We also assigned three different molting categories to Nearctic species, following Pyle (1997) and Rohwer et al. (2005): species that molt after breeding within their breeding range during the summer period (summer molt); species that molt in the Mexican monsoon region during a stopover in their fall migration (stopover molt); and species that molt on their wintering grounds after the completion of fall migration (winter molt). For the Painted Bunting (Passerina ciris), the molting pattern differs depending on the geographic origin of individuals (Thompson 1991). In our study, we assigned a stopover molt to this species in accordance with the origin of the birds whose feathers were measured (we included only Painted Bunting feathers from individuals that bred in Texas). It is important to note that stopover and winter molt occur only in fully migratory species. Thus, we combined migratory behavior and molt pattern to establish five groups of species that represent the life-history strategies that exist in the Nearctic region: (1) sedentary species with summer molt ( $n=14$ species), (2) partially migratory species with summer molt $(n=17)$, (3) fully migratory species with summer molt $(n=$ $53)$, (4) fully migratory species with stopover molt $(n=6)$, and (5) fully migratory species with winter molt $(n=8)$.
Statistical analyses.-For each species, we used the mean value of feather growth rate, feather mass, and feather length in statistical analyses. Such feather traits showed high and significant repeatability among species as derived from the calculation of the intraclass correlation coefficients $r_{\mathrm{i}}$ (feather growth rate: $r_{\mathrm{i}}=0.89, F=51.16, \mathrm{df}=97$ and 491, $P<0.001$; feather mass: $r_{\mathrm{i}}=$ $0.98, F=257.1, \mathrm{df}=97$ and 491, $P<0.001$; feather length: $r_{\mathrm{i}}=0.96$, $F=144.9, \mathrm{df}=97$ and $491, P<0.001)$. Mean values of feather measurements were logarithmically transformed for a better fit to a normal distribution (all $P>0.20$ in Kolmogorov-Smirnov tests). In order to explore the variation in feather growth rate and feather mass among groups with different life-history strategies, we performed two analyses of covariance (ANCOVA) in which feather growth rate and mass were included as dependent variables, life-history strategy as a fixed effect (five categories), and feather length as the covariate. The degrees of freedom of these tests are inflated because they equivocally consider species as independent data points; therefore, we performed the empirically scaled computer simulation models suggested by Garland et al. (1993) to obtain more reliable significance levels that account for the phylogenetic relationships among species (Felsenstein 1985). For that purpose, we constructed a phylogeny from a larger tree of passerine species (Jønsson and Fjeldså 2006) that was also complemented by other phylogenetic hypotheses for particular groups (the phylogeny used is available from the authors upon request): Gill et al. (2005) for Paridae; Lovette and Bermingham (1999) for the genus Dendroica; Lovette and Bermingham (2002) for Parulidae; Burns (1998) for the genus Piranga; Klicka et al. (2001) for the genus Passerina; Marten and Johnson (1986) for the genus Carpodacus; and Johnson and Cicero (2002), Cicero and Johnson (2002), and Ohlson et al. (2008) for the suborder Tyranni (suboscines). We established politomies for groups with unknown phylogenetic relationships or contradictory information.

Following Garland et al. (1993), we first imputed original feather-measurement data and the phylogenetic relationships among species in PDTREE program. Next, we used PDSIMUL to simulate $1,000 \times$ the evolution of feather traits along our phylogenetic tree, which generated 1,000 simulated data sets of feather growth rate, feather mass, and feather length for the 98 species considered in the study. In the simulations, feather length was bounded between the tail length of the smallest bird in North America (i.e., Calliope Hummingbird [Stellula calliope], lower limit for feather length $=20 \mathrm{~mm}$ ) and that of the largest passerine in the Holarctic region (i.e., Common Raven [Corvus corax], upper limit for feather length $=245 \mathrm{~mm}$ ). The limits for feather growth rate were obtained by including the previously mentioned values of feather length in the relationship between feather growth rate and feather length for the 98 species included in the study $\left(\log _{10}[\right.$ feather growth rate $]=0.194+0.709 * \log _{10}$ [feather length]; logarithmically expressed, lower and upper limits for feather growth rate were 1.12 and $1.89 \mathrm{~mm}$, respectively). The upper limit for the simulations of feather mass was also obtained by including the upper limit of feather length in the relationship between feather mass and feather length for the 98 studied species $\left(\log _{10}\right.$ [feather mass] $=-4.397+2.964 * \log _{10}$ [feather length]; upper limit for feather mass was $2.68 \mathrm{mg}$, logarithmically expressed). However, given that the inclusion of the feather length of Calliope Hummingbird in the equation relating feather mass 
and feather length provided a negative value, the lower limit for feather mass was set arbitrarily to $2 \mathrm{mg}$ (i.e., $0.3 \mathrm{mg}$ after logarithmic transformation).

We conducted the simulations using the REPLACE option in PDSIMUL, using between-species means both as starting values and as the expected means of the generated tip values. The expected variances of the simulated tip data were set equal to the variances of the real data. The correlations between the simulated changes for each pair of traits were set to zero. Branch lengths of our phylogenetic hypothesis could not be estimated because our phylogeny was constructed from different bibliographic sources that did not use the same methodological procedures. For this reason, all branch lengths were set equal to unity, thereby assuming a speciational model of evolutionary change in which most change is expected to occur in association with speciation events (Rohlf et al. 1990). Finally, we used the program PDANOVA to analyze all sets of simulated data and to obtain null distributions of $F$ statistics for ANCOVA (Garland et al. 1993). Such procedure allows setting critical values for hypothesis testing that account for the lack of independence among species. Thus, more correct $P$ values can be obtained by dividing the number of $F$ values derived from simulated data that exceed the empirical $F$ value (the one obtained in the non-phylogenetic ANCOVA) by the number of simulations performed.

\section{Results}

Feather growth rate differed among groups in both the conventional and phylogenetic ANCOVA $(F=9.94, \mathrm{df}=4$ and 92, conventional $P<0.001$, phylogenetically correct $P=0.040$; Fig. 1 ), after controlling for the effects of feather length (feather length was strongly correlated with feather growth rate; $F=698.4, \mathrm{df}=1$

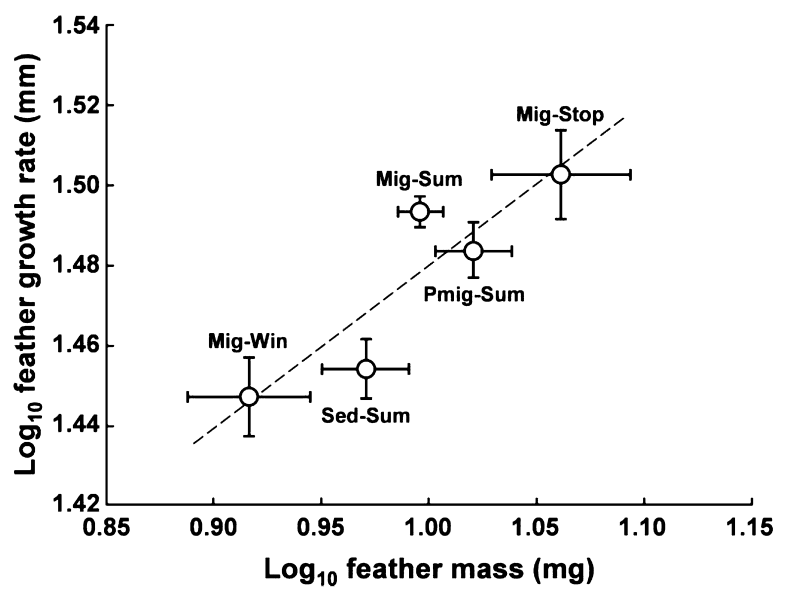

FIG. 1. Variation in feather growth rate ( $y$-axis) and mass ( $x$-axis) among five groups of species that differ in life-history strategies: sedentary species with summer molt (Sed-Sum), partially migratory species with summer molt (Pmig-Sum), fully migratory species with summer molt (Mig-Sum), fully migratory species with stopover molt (Mig-Stop), and fully migratory species with winter molt (Mig-Win). Graph shows mean values adjusted by feather length and standard errors. The regression line derived from the relationship between feather growth rate and mass for the five groups of species is also shown. and $92, \beta=0.951, P<0.001$ in both conventional and phylogenetically corrected analyses; Fig. 2A). For species molting within the breeding range during summer, we observed a marked increase in feather growth rate from sedentary to migratory species (both partially and fully migratory species; see $y$-axis in Fig. 1). However, winter-molting migratory species showed feather growth rates similar to the values observed for sedentary species. By contrast, migratory species that undergo a stopover molt showed the highest mean values of feather growth rate, which were similar to the values observed for summer-molting migrants (Fig. 1). The effects of feather length on feather growth rate did not differ among groups (homogeneity of slopes test: $F=0.15, \mathrm{df}=4$ and 88 , conventional $P=0.964$, phylogenetically corrected $P=0.831$ ), but the slope of the relationship between feather growth rate and feather length was significantly lower than the slope expected according to isometry (observed allometric coefficient $b=0.736 \mathrm{vs}$. expected $b=1 ; t=-9.48, \mathrm{df}=92, P<0.001$; Fig. $2 \mathrm{~A}$ ).

Feather length was also strongly correlated with feather mass $(F=1390.3$, df $=1$ and $92, \beta=0.967, P<0.001$ in both conventional and phylogenetically corrected analyses), with an isometric relationship between the two variables (observed $b=2.971 \mathrm{vs.}$ expected $b=3 ; t=0.36, \mathrm{df}=92, P=0.718$; Fig. $2 \mathrm{~B}$ ) and without significant effects of the interaction between group and
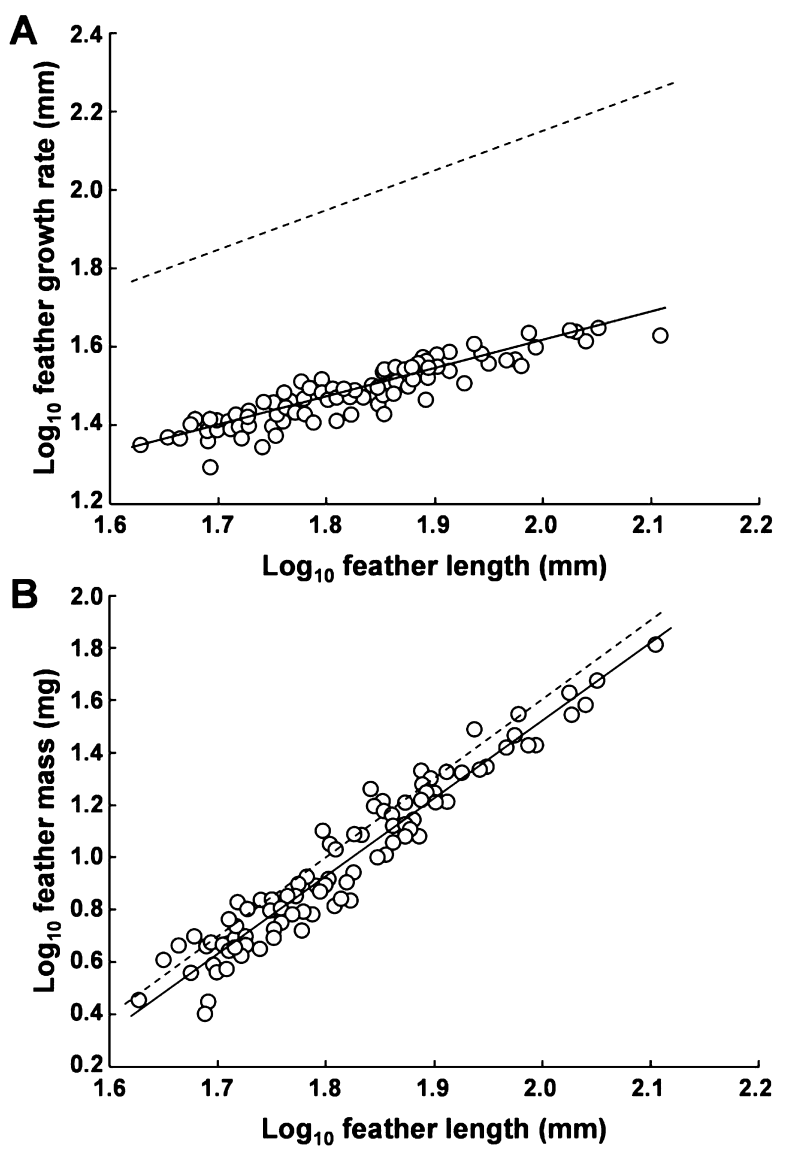

FIG. 2. Relationships of feather length with (A) feather growth rate and (B) feather mass for the 98 passerine species included in the study. Each graph shows the observed regression line (solid line) and the expected line if there was an isometric relationship with feather length (broken line). 
feather length (homogeneity of slopes test: $F=1.37, \mathrm{df}=4$ and 88 , conventional $P=0.250$, phylogenetically correct $P=0.446$ ). After controlling for the effects of feather length, we also detected a significant effect of group on feather mass in the conventional analysis $(F=3.98, \mathrm{df}=4$ and $92, P=0.005$; see $x$-axis in Fig. 1$)$, but this effect lost its significance when the phylogenetic relationships among species were taken into account (phylogenetically correct $P=0.337$ ). Interestingly, as in the analysis of feather growth rate, species that undergo a stopover molt and winter-molting migratory species showed, respectively, the highest and the lowest mean values of tail feather mass, which caused a significant positive association between (length-corrected) feather growth rate and (length-corrected) feather mass among groups $(r=0.902$, $F=13.08, \mathrm{df}=1$ and $3, P=0.036$; Fig. 1 ).

\section{Discussion}

Our comparative analysis of feather growth rate supported the existence of differences in molt duration among groups of Nearctic species with different migratory behaviors and molt patterns. If variation in feather growth rate is indeed associated with molt duration, as is assumed according to previous research (de la Hera et al. 2011), our results for Nearctic species were coincident with two of the main patterns described for Palearctic passerines. First, migration was associated with an acceleration of feather growth rate (i.e., molts of shorter duration), but only for species molting on the breeding grounds during summer. Such reduction in molt duration in migratory species compared with sedentary ones agrees with the idea that migration constrains the time available between breeding and autumn migration for molting (Hedenström 2008, de la Hera et al. 2009a). Second, the feather growth rates of winter-molting migratory species were slower than those of summer-molting migratory species, but similar to those of sedentary species. In the present study, 7 of the 8 winter-molting species were aerial foragers and, therefore, species that need to molt slowly to maintain their ability to capture insects in flight (Butler et al. 2006). If summer molt is also the ancestral pattern in Nearctic passerines, as it appears to be in Palearctic passerines (Svensson and Hedenström 1999, Hall and Tullberg 2004), this result would support the hypothesis that winter molt evolved as a strategy to skip the temporal constraints experienced during summer, when there is insufficient time for the long molt duration required by aerial foragers (Rohwer et al. 2005). In the case of species that undergo a stopover molt, an apparently uncommon strategy in the Palearctic region (see Hedenström et al. 1993), the observed high feather growth rates suggest that they have the shortest molt durations among all Nearctic passerines. Such a possibility has been proposed by Voelker $(2000,2004)$, who suggested that rapid molts would be possible in northwestern Mexico thanks to the flush of productivity occurring during the late summer monsoon season.

The existence of a tradeoff between feather growth rate and feather mass in birds would predict a negative association between the two variables (Dawson et al. 2000, Serra 2001, de la Hera et al. 2010b). Unexpectedly, the variation in feather growth rate observed in the present study was not negatively correlated with feather mass. Rather, the relationship among groups between these two variables was positive: species with high feather growth rates had heavier tail feathers than species that produced their feathers more slowly. Such positive association might be interpreted as a result of the variation among groups in the quantity or quality of food resources available for molting (van Noordwijk and de Jong 1986, de la Hera et al. 2009b). Such variation could be mediated by the occupancy of distant geographic areas, where environmental conditions for molting can be markedly different. As mentioned above, species that molt in northwestern Mexico can benefit during molt from the late-summer peak of productivity brought on by the North American monsoon, which would allow them both to molt rapidly and to produce structurally complex (heavy) feathers (Voelker 2000, 2004). The suitability of this region for molting, at least in terms of food availability, is also supported by the fact that several local sedentary species are able to overlap breeding and molting during summer (Rohwer et al. 2009b), which would be possible only if food resources were abundant. On the other hand, species that had a winter molt produced light feathers in spite of their slow growth rate, which might suggest that winter-molting species occupy habitats with lower availability of resources for molting than do the other groups. This result would represent a remarkable difference from the observations made in the Palearctic-African bird migration system, where winter-molting species molted more slowly but produced better-quality feathers than summer-molting migrants (de la Hera et al. 2010b). In any case, the conclusions derived in the present study from the analysis of feather mass should be taken with caution, because we did not control for the differences among species in feather structure caused by a particular lifestyle or by the occupancy of different habitats (Rohwer et al. 2005, de la Hera et al. 2010b). Consequently, our hypotheses will require further testing.

In summary, our results support the view that temporal constraints during summer could be a main determinant favoring winter molt, whereas stopover molt could be more related to the benefits of molting in a location with abundant food resources. The fact that most migratory species that undergo a stopover molt breed in western North America, where conditions are very dry and unsuitable for molting after reproduction, also reinforces the idea that food availability plays a more important role than temporal pressures in promoting stopover molt (Rohwer et al. 2005).

An ancillary result from this study was that the scaling relationship between feather growth rate and feather length was allometric. Thus, feather growth rate increased less than expected with the increment of feather length (Fig. 2A). Such limitation in the growth rate of feathers has been previously illustrated in primary flight feathers and has been suggested to explain why birds with long feathers (or large birds) require relatively more time for molting their plumage than birds with short feathers (or small birds), leading to the evolution of simultaneous or stepwise primary replacement in large (nonpasserine) species (Rohwer et al. 2009a). It has been suggested that this negative allometry between feather growth rate and feather length might be caused by the production of comparatively heavier feathers in large species compared with small species (Rohwer et al. 2009a). However, that possibility was ruled out by our demonstration of an isometric relationship between feather mass and feather length, which also confirms the pattern observed by Dawson (2005) in primary wing feathers.

All the findings derived from our study emphasize the usefulness of individual feather analysis to improve our understanding 
of the evolution of molt. Likewise, our results underscore the importance of implementing similar approaches in other geographic contexts (such as tropical areas or temperate regions of the Southern Hemisphere), where both comparable estimates of molt duration and a proper knowledge of the diversification of molt patterns are lacking (Ryder and Wolfe 2009, Bridge 2011).

\section{ACKNOWLEDGMENTS}

This study was possible thanks to the voluntary work of many banders across North America who took part in feather collection within the protocols of the Monitoring Avian Productivity and Survivorship (MAPS) program. We are also very grateful to J. Pollinger, A. Alvarado, E. Curd, and T. Smith for their help during feather analyses at the University of California, Los Angeles, and J. Pérez-Tris and J. L. Tellería for encouraging the initiation of this study. I. de la Hera was funded by the Department of Education, Universities and Research of the Basque Government (studentships BFI. 04-33 and 09-13). This is contribution no. 418 of The Institute for Bird Populations.

\section{Literature Cited}

Alsop, F. J., III. 2001. Birds of North America: Life Histories of More Than 930 species. Covent Garden Press, New York.

Barta, Z., A. I. Houston, J. M. McNamara, R. K. Welham, A. Hedenström, T. P. Weber, And O. Feró. 2006. Annual routines of non-migratory birds: Optimal moult strategies. Oikos 112:580-593.

Barta, Z., J. M. McNamara, A. I. Houston, T. P. Weber, A. Hedenström, ANd O. Feró. 2008. Optimal moult strategies in migratory birds. Philosophical Transactions of the Royal Society of London, Series B 363:211-229.

BRIDGE, E. S. 2011. Mind the gaps: What's missing in our understanding of feather molt. Condor 113:1-4.

Brodin, A. 1993. Radio-ptilochronology: Tracing radioactively labelled food in feathers. Ornis Scandinavica 24:167-173.

Burns, K. J. 1998. Molecular phylogenetics of the genus Piranga: Implications for biogeography and the evolution of morphology and behavior. Auk 115:621-634.

Butler, L. K., S. Rohwer, And M. Rogers. 2006. Prebasic molt and molt-related movements in Ash-throated Flycatchers. Condor 108:647-660.

Chambers, M., G. David, C. Ray, B. Leitner, and P. Pyle. 2011. Habitats and conservation of molt-migrant birds in southeastern Arizona. Southwestern Naturalist 56:204-211.

Cicero, C., And N. K. Johnson. 2002. Phylogeny and character evolution in the Empidonax group of Tyrant Flycatchers (Aves: Tyrannidae): A test of W. E. Lanyon's hypothesis using mtDNA sequences. Molecular Phylogenetics and Evolution 22:289-302.

Dawson, A. 2005. The scaling of primary flight feather length and mass in relation to wing shape, function and habitat. Ibis 147:283-292.

Dawson, A., S. A. Hinsley, P. N. Ferns, R. H. C. Bonser, and L. ECCLESTON. 2000. Rate of moult affects feather quality: A mechanism linking current reproductive effort to future survival. Proceedings of the Royal Society of London, Series B 267:2093-2098. de la Hera, I., J. A. Díaz, J. Pérez-Tris, and J. L. Tellería. 2009a. A comparative study of migratory behaviour and body mass as determinants of moult duration in passerines. Journal of Avian Biology 40:461-465.

de la Hera, I., A. Hedenström, J. Pérez-Tris, and J. L. TellERÍA. 2010a. Variation in the mechanical properties of flight feathers of the Blackcap Sylvia atricapilla in relation to migration. Journal of Avian Biology 41:342-347.

de la Hera, I., J. Pérez-Tris, and J. L. Tellería. 2009b. Migratory behaviour affects the trade-off between feather growth rate and feather quality in a passerine bird. Biological Journal of the Linnean Society 97:98-105.

de la Hera, I., J. Pérez-Tris, and J. L. Tellería. 2010b. Relationships among timing of moult, moult duration and feather mass in long-distance migratory passerines. Journal of Avian Biology 41:609-614.

de la Hera, I., S. V. Schaper, J. A. Díaz, J. Pérez-Tris, S. Bensch, AND J. L. Tellería. 2011. How much variation in the molt duration of passerines can be explained by the growth rate of tail feathers? Auk 128:321-329.

DeSAnte, D. F., AND D. R. KASChube. 2009. The monitoring avian productivity and survivorship (MAPS) program 2004, 2005, and 2006 annual report. Bird Populations 9:86-169.

Felsenstein, J. 1985. Phylogenies and the comparative method. American Naturalist 125:1-15.

Garland, T., JR., A. W. Dickerman, C. M. Janis, and J. A. Jones. 1993. Phylogenetic analysis of covariance by computer simulation. Systematic Biology 42:265-292.

Gill, F. B., B. Slikas, AND F. H. Sheldon. 2005. Phylogeny of titmice (Paridae): II. Species relationships based on sequences of the mitochondrial cytochrome- $b$ gene. Auk 122:121-143.

Ginn, H. B., AND D. S. Melville. 1983. Moult in Birds. BTO, Tring, United Kingdom.

Griggio, M., L. Serra, D. Licheri, C. Campomori, and A. PilasTRO. 2009. Moult speed affects structural feather ornaments in the Blue Tit. Journal of Evolutionary Biology 22:782-792.

GrubB, T. C., JR. 2006. Ptilochronology: Feather Time and the Biology of Birds. Oxford University Press, New York.

Hall, K. S. S., AND B. S. Tullberg. 2004. Phylogenetic analyses of the diversity of moult strategies in Sylviidae in relation to migration. Evolutionary Ecology 18:85-105.

Hedenström, A. 2008. Adaptations to migration in birds: Behavioural strategies, morphology and scaling effects. Philosophical Transactions of the Royal Society of London, Series B 363:287-299.

Hedenström, A., S. Bensch, D. Hasselquist, M. Lockwood, And U. Отtosson. 1993. Migration, stopover and moult of the Great Reed Warbler Acrocephalus arundinaceus in Ghana, WestAfrica. Ibis 135:177-180.

Jenni, L., AND R. WinkLer. 1994. Moult and Ageing of European Passerines. Academic Press, London.

Johnson, N. K., AND C. CiCERO. 2002. The role of ecologic diversification in sibling speciation of Empidonax flycatchers (Tyrannidae): Multigene evidence from mtDNA. Molecular Ecology 11:2065-2081.

JønSSON, K. A., AND J. FJELDSÅ. 2006. A phylogenetic supertree of oscine passerine birds (Aves: Passeri). Zoologica Scripta 35:149-186. 
KJELLÉN, N. 1994. Moult in relation to migration in birds-A review. Ornis Svecica 4:1-21.

Klicka, J., A. J. Fry, R. M. Zink, And C. W. Thompson. 2001. A cytochrome- $b$ perspective on Passerina bunting relationships. Auk 118:611-623.

Lovette, I. J., And E. Bermingham. 1999. Explosive speciation in the New World Dendroica warblers. Proceedings of the Royal Society of London, Series B 266:1629-1636.

Lovette, I. J., And E. Bermingham. 2002. What is a woodwarbler? Molecular characterization of a monophyletic parulidae. Auk 119:695-714.

MARTEN, J. A., AND N. K. Johnson. 1986. Genetic relationships of North American cardueline finches. Condor 88:409-420.

Moreau, R. E. 1972. The Palearctic-African Bird Migration Systems. Academic Press, New York.

Ohlson, J., J. FJelds ̊, And P. G. P. ERicson. 2008. Tyrant flycatchers coming out in the open: Phylogeny and ecological radiation of Tyrannidae (Aves, Passeriformes). Zoologica Scripta 37:315-335.

Pyle, P. 1997. Identification Guide to North American Birds, Part 1: Columbidae to Ploceidae. Slate Creek Press, Bolinas, California.

Pyle, P., W. A. Leitner, L. Lozano-Angulo, F. Avilez-Teran, H. Swanson, E. Gómez Limón, and M. K. Chambers. 2009. Temporal, spatial, and annual variation in the occurrence of molt-migrant passerines in the Mexican monsoon region. Condor 111:583-590.

Rohlf, F. J., W. S. Chang, R. R. Sokal, And J. Kim. 1990. Accuracy of estimated phylogenies: Effects of tree topology and evolutionary model. Evolution 44:1671-1684.

Rohwer, S., L. K. Butler, and D. R. Froehlich. 2005. Ecology and demography of east-west differences in molt scheduling of Neotropical migrant passerines. Pages 87-105 in Birds of Two Worlds: The Ecology and Evolution of Migration (R. Greenberg and P. P. Marra, Eds.). Johns Hopkins University Press, Baltimore.
Rohwer, S., R. E. Ricklefs, V. G. Rohwer, And M. M. Copple. 2009a. Allometry of the duration of flight feather molt in birds. PLoS Biology 7:e1000132.

Rohwer, V. G., S. Rohwer, And M. F. Ortiz-Ramirez. 2009b. Molt biology of resident and migrant birds of the monsoon region of west Mexico. Ornitologia Neotropical 20:565-584.

Rohwer, S., A. Viggiano, And J. M. Marzluff. 2011. Reciprocal tradeoffs between molt and breeding in albatrosses. Condor 113:61-70.

Ryder, T. B., AND J. D. WOLfE. 2009. The current state of knowledge on molt and plumage sequences in selected Neotropical bird families: A review. Ornitologia Neotropical 20:1-18.

SERRA, L. 2001. Duration of primary moult affects primary quality in Grey Plovers Pluvialis squatarola. Journal of Avian Biology 32:377-380.

Serra, L., S. Pirrello, D. Licheri, M. Griggio, and A. PilasTRO. 2010. Sex-dependent response of primary moult to simulated time constraints in the Rock Sparrow Petronia petronia. Journal of Avian Biology 41:327-335.

Svensson, E., And A. Hedenström. 1999. A phylogenetic analysis of the evolution of moult strategies in western Palearctic warblers (Aves: Sylviidae). Biological Journal of the Linnean Society 67:263-276.

Thompson, C. W. 1991. Is the Painted Bunting actually two species? Problems determining species limits between allopatric populations. Condor 93:987-1000.

VAN NOORDWIJK, A. J., AND G. DE JONG. 1986. Acquisition and allocation of resources: Their influence on variation in life history tactics. American Naturalist 128:137-142.

Voelker, G. 2000. Molt of the Gray Vireo. Condor 102:610-618.

VoelKer, G. 2004. Can migrants do it faster? Accelerated molt of Baird's Sparrows and further insights into southwestern molting grounds. Condor 106:910-914.

Associate Editor: L. Butler 
APPENDIX. Mean raw values ( \pm SE) of feather growth rate, feather mass, and feather length for the 98 species considered in our study. Sample sizes and the migratory behavior and molting pattern of each species are also shown.

\begin{tabular}{|c|c|c|c|c|c|c|}
\hline Scientific name & $\begin{array}{l}\text { Migratory } \\
\text { behavior }\end{array}$ & $\begin{array}{l}\text { Molt } \\
\text { pattern }\end{array}$ & $n$ & $\begin{array}{l}\text { Feather growth } \\
\text { rate (mm/10 days) }\end{array}$ & $\begin{array}{l}\text { Feather mass } \\
\qquad(\mathrm{mg})\end{array}$ & $\begin{array}{l}\text { Feather length } \\
\qquad(\mathrm{mm})\end{array}$ \\
\hline Agelaius phoeniceus & Migratory & Summer & 8 & $41.35 \pm 1.31$ & $31.6 \pm 3.94$ & $86.34 \pm 3.9$ \\
\hline Amphispiza bilineata & Partial migrant & Summer & 6 & $32.64 \pm 0.41$ & $7.95 \pm 0.29$ & $62.4 \pm 1.01$ \\
\hline Baeolophus bicolor & Sedentary & Summer & 7 & $30.14 \pm 0.27$ & $10.2 \pm 0.37$ & $71.2 \pm 0.94$ \\
\hline Bombycilla cedrorum & Migratory & Summer & 8 & $30.6 \pm 0.54$ & $11.68 \pm 0.26$ & $63.53 \pm 0.59$ \\
\hline Cardellina canadensis & Migratory & Summer & 4 & $27.1 \pm 0.74$ & $4.7 \pm 0.23$ & $53.35 \pm 1.47$ \\
\hline C. pusilla & Migratory & Summer & 4 & $25.82 \pm 0.3$ & $3.73 \pm 0.13$ & $51.03 \pm 1.29$ \\
\hline C.cardinalis & Sedentary & Summer & 9 & $40.16 \pm 1.02$ & $27.57 \pm 1.04$ & $98.58 \pm 2.21$ \\
\hline Carpodacus cassinii & Partial migrant & Summer & 8 & $29.94 \pm 0.25$ & $12.4 \pm 0.42$ & $67.83 \pm 0.61$ \\
\hline C. mexicanus & Partial migrant & Summer & 8 & $30.06 \pm 0.56$ & $12.38 \pm 0.3$ & $66.99 \pm 0.74$ \\
\hline C. purpureus & Partial migrant & Summer & 10 & $29.96 \pm 0.45$ & $10.93 \pm 0.27$ & $64.21 \pm 0.86$ \\
\hline Catharus fuscescens & Migratory & Summer & 7 & $36.38 \pm 0.98$ & $14.09 \pm 0.8$ & $76.31 \pm 2.2$ \\
\hline Catharus guttatus & Partial migrant & Summer & 2 & $35.07 \pm 1.67$ & $13.55 \pm 2.15$ & $74.49 \pm 5$ \\
\hline C. minimus & Migratory & Summer & 6 & $38.57 \pm 1.25$ & $16.75 \pm 0.51$ & $81.59 \pm 1.06$ \\
\hline C. ustulatus & Migratory & Summer & 4 & $35.89 \pm 1.2$ & $13.95 \pm 0.44$ & $75.67 \pm 1.14$ \\
\hline Coccothraustes vespertinus & Partial migrant & Summer & 7 & $31.56 \pm 0.82$ & $18.53 \pm 0.89$ & $69.71 \pm 1.18$ \\
\hline Contopus cooperi & Migratory & Winter & 3 & $29.74 \pm 1.84$ & $16.63 \pm 1.12$ & $77.83 \pm 1.12$ \\
\hline C. sordidulus & Migratory & Winter & 4 & $26.89 \pm 0.58$ & $10.4 \pm 0.31$ & $71.37 \pm 0.49$ \\
\hline C. virens & Migratory & Winter & 3 & $28.39 \pm 0.51$ & $10.1 \pm 0.5$ & $70.32 \pm 1.29$ \\
\hline Cyanocitta cristata & Migratory & Summer & 7 & $45.15 \pm 0.87$ & $47.77 \pm 1.44$ & $112.66 \pm 1.16$ \\
\hline C. stelleri & Sedentary & Summer & 9 & $43.03 \pm 0.99$ & $67.68 \pm 1.3$ & $128.29 \pm 1.1$ \\
\hline Dumetella carolinensis & Partial migrant & Summer & 7 & $38.71 \pm 0.94$ & $22.43 \pm 0.65$ & $87.67 \pm 0.78$ \\
\hline Empidonax difficilis & Migratory & Winter & 7 & $26.12 \pm 0.38$ & $5.96 \pm 0.23$ & $61.26 \pm 0.58$ \\
\hline E. fulvifrons & Migratory & Summer & 9 & $24.07 \pm 0.48$ & $4.98 \pm 0.16$ & $56.56 \pm 1.06$ \\
\hline E. oberholseri & Migratory & Winter & 3 & $26.11 \pm 0.74$ & $6.7 \pm 0.65$ & $64.27 \pm 2.31$ \\
\hline E. occidentalis & Migratory & Winter & 3 & $27.02 \pm 0.25$ & $6.83 \pm 0.35$ & $66.35 \pm 0.25$ \\
\hline E. virescens & Migratory & Summer & 4 & $29.63 \pm 0.56$ & $6.3 \pm 0.13$ & $60.11 \pm 1.17$ \\
\hline E. wrightii & Migratory & Winter & 4 & $31.7 \pm 1.13$ & $7 \pm 0.33$ & $65.55 \pm 1.25$ \\
\hline Geothlypis formosa & Migratory & Summer & 8 & $25.9 \pm 0.47$ & $4.79 \pm 0.16$ & $51.12 \pm 0.83$ \\
\hline G. philadelphia & Migratory & Summer & 7 & $24.72 \pm 0.8$ & $4.64 \pm 0.08$ & $49.08 \pm 0.88$ \\
\hline G. tolmiei & Migratory & Summer & 6 & $26.17 \pm 0.54$ & $5.77 \pm 0.27$ & $57.33 \pm 1.06$ \\
\hline G. trichas & Migratory & Summer & 7 & $24.89 \pm 0.5$ & $4.73 \pm 0.13$ & $50.74 \pm 0.52$ \\
\hline Helmitheros vermivorum & Migratory & Summer & 6 & $27.2 \pm 0.6$ & $5.22 \pm 0.18$ & $52.08 \pm 0.5$ \\
\hline Hylocichla mustelina & Migratory & Summer & 8 & $34.06 \pm 1.11$ & $17.99 \pm 0.52$ & $78.37 \pm 1.3$ \\
\hline Icteria virens & Migratory & Summer & 9 & $37.32 \pm 0.93$ & $12.28 \pm 0.37$ & $76.69 \pm 1.76$ \\
\hline Icterus bullockii & Migratory & Stopover & 8 & $35.9 \pm 0.85$ & $20.51 \pm 0.44$ & $78.81 \pm 1.09$ \\
\hline I. galbula & Migratory & Summer & 6 & $35.13 \pm 0.89$ & $16.7 \pm 0.37$ & $71.29 \pm 1.03$ \\
\hline Ixoreus naevius & Migratory & Summer & 5 & $36.04 \pm 1.05$ & $36.04 \pm 1.25$ & $95.3 \pm 1.38$ \\
\hline Junco hyemalis & Partial migrant & Summer & 4 & $30.89 \pm 0.57$ & $8.85 \pm 0.17$ & $66.84 \pm 0.7$ \\
\hline J. phaeonotus & Sedentary & Summer & 6 & $30.72 \pm 0.96$ & $11.5 \pm 0.83$ & $72.89 \pm 1.15$ \\
\hline Limnothlypis swainsonii & Migratory & Summer & 8 & $25.8 \pm 0.31$ & $5.61 \pm 0.19$ & $52.26 \pm 0.63$ \\
\hline Melospiza georgiana & Migratory & Summer & 4 & $27.34 \pm 1.01$ & $6.1 \pm 0.15$ & $58.79 \pm 1.44$ \\
\hline M. lincolnii & Migratory & Summer & 6 & $25.15 \pm 1.06$ & $6.4 \pm 0.33$ & $56.15 \pm 1.43$ \\
\hline M. melodia & Partial migrant & Summer & 7 & $29.54 \pm 0.7$ & $8.51 \pm 0.57$ & $63.62 \pm 1.61$ \\
\hline Mimus polyglottos & Sedentary & Summer & 6 & $43.98 \pm 0.71$ & $36.1 \pm 2.06$ & $106.45 \pm 2.14$ \\
\hline Mniotilta varia & Migratory & Summer & 4 & $27.71 \pm 0.46$ & $4.98 \pm 0.17$ & $53.37 \pm 0.91$ \\
\hline Molothrus ater & Partial migrant & Summer & 9 & $37.9 \pm 1.53$ & $22.1 \pm 1.86$ & $77.4 \pm 1.98$ \\
\hline Myiarchus crinitus & Migratory & Summer & 4 & $43.57 \pm 0.69$ & $27.18 \pm 0.83$ & $96.8 \pm 2.64$ \\
\hline Oreothlypis celata & Migratory & Summer & 4 & $25.7 \pm 1.09$ & $4.58 \pm 0.26$ & $51.41 \pm 1.54$ \\
\hline O. virginiae & Migratory & Summer & 5 & $25.91 \pm 0.76$ & $4.46 \pm 0.2$ & $51.66 \pm 1.31$ \\
\hline Parkesia motacilla & Migratory & Summer & 7 & $28.98 \pm 0.99$ & $7.04 \pm 0.29$ & $56.17 \pm 1.04$ \\
\hline P. noveboracensis & Migratory & Summer & 5 & $30.66 \pm 1.45$ & $6.64 \pm 0.43$ & $57.37 \pm 2.58$ \\
\hline Passer domesticus & Sedentary & Summer & 3 & $30.3 \pm 0.56$ & $12.93 \pm 0.41$ & $62.93 \pm 0.8$ \\
\hline Passerella iliaca & Migratory & Summer & 9 & $35.95 \pm 0.64$ & $16.67 \pm 0.33$ & $77.78 \pm 0.7$ \\
\hline Passerina amoena & Migratory & Stopover & 5 & $32.3 \pm 0.48$ & $8.04 \pm 0.37$ & $59.73 \pm 0.84$ \\
\hline P. caerulea & Migratory & Winter & 9 & $35.5 \pm 0.4$ & $15.19 \pm 0.39$ & $71.62 \pm 0.76$ \\
\hline P. ciris & Migratory & Stopover & 5 & $31.3 \pm 0.46$ & $8.66 \pm 0.3$ & $60.84 \pm 1.02$ \\
\hline P. cyanea & Migratory & Summer & 5 & $29.06 \pm 0.97$ & $6.88 \pm 0.25$ & $55.04 \pm 1.36$ \\
\hline Pheucticus ludovicianus & Migratory & Summer & 6 & $36.77 \pm 0.69$ & $19.33 \pm 0.85$ & $77.59 \pm 1.7$ \\
\hline P. melanocephalus & Migratory & Stopover & 7 & $34.71 \pm 0.69$ & $21.76 \pm 0.89$ & $82.03 \pm 0.78$ \\
\hline
\end{tabular}


ApPENDIX. Continued

\begin{tabular}{|c|c|c|c|c|c|c|}
\hline Scientific name & $\begin{array}{l}\text { Migratory } \\
\text { behavior }\end{array}$ & $\begin{array}{c}\text { Molt } \\
\text { pattern }\end{array}$ & $n$ & $\begin{array}{l}\text { Feather growth } \\
\text { rate (mm/10 days) }\end{array}$ & $\begin{array}{l}\text { Feather mass } \\
\qquad(\mathrm{mg})\end{array}$ & $\begin{array}{c}\text { Feather length } \\
(\mathrm{mm})\end{array}$ \\
\hline Pipilo crissalis & Sedentary & Summer & 8 & $37.03 \pm 0.91$ & $29.33 \pm 1.93$ & $94.58 \pm 3.17$ \\
\hline P. erythrophthalmus & Partial migrant & Summer & 8 & $36.5 \pm 0.4$ & $22.58 \pm 0.69$ & $88.91 \pm 1.28$ \\
\hline P. fuscus & Sedentary & Summer & 4 & $36.8 \pm 1.78$ & $26.88 \pm 1.41$ & $92.36 \pm 2.33$ \\
\hline Piranga flava & Migratory & Summer & 7 & $32.41 \pm 1.05$ & $21.63 \pm 0.46$ & $84.42 \pm 0.64$ \\
\hline P. ludoviciana & Migratory & Stopover & 8 & $35.76 \pm 0.69$ & $16.8 \pm 0.71$ & $77.42 \pm 1.27$ \\
\hline P. olivacea & Migratory & Summer & 9 & $35.84 \pm 0.43$ & $14.82 \pm 0.4$ & $72.82 \pm 0.61$ \\
\hline P. rubra & Migratory & Summer & 5 & $38.27 \pm 0.26$ & $17.66 \pm 1.07$ & $79.68 \pm 2.49$ \\
\hline Poecile atricapillus & Sedentary & Summer & 6 & $26.77 \pm 0.99$ & $5.35 \pm 0.11$ & $59.92 \pm 1.46$ \\
\hline P. carolinensis & Sedentary & Summer & 9 & $23.35 \pm 0.46$ & $4.32 \pm 0.1$ & $52.84 \pm 0.78$ \\
\hline Protonotaria citrea & Migratory & Summer & 5 & $26.16 \pm 0.64$ & $4.98 \pm 0.26$ & $47.67 \pm 0.98$ \\
\hline Psaltriparus minimus & Sedentary & Summer & 8 & $19.65 \pm 0.38$ & $2.83 \pm 0.08$ & $49.28 \pm 1.3$ \\
\hline Regulus calendula & Migratory & Summer & 4 & $22.99 \pm 0.42$ & $2.58 \pm 0.11$ & $49.14 \pm 0.33$ \\
\hline Sayornis phoebe & Partial migrant & Summer & 6 & $31.66 \pm 0.52$ & $12.45 \pm 0.52$ & $75.03 \pm 0.82$ \\
\hline Seiurus aurocapilla & Migratory & Summer & 6 & $28.9 \pm 0.8$ & $7.18 \pm 0.69$ & $58.3 \pm 1.61$ \\
\hline Setophaga americana & Migratory & Summer & 5 & $22.44 \pm 0.86$ & $2.88 \pm 0.19$ & $42.34 \pm 0.57$ \\
\hline S. citrina & Migratory & Summer & 6 & $26.95 \pm 0.35$ & $5.37 \pm 0.17$ & $56.63 \pm 0.82$ \\
\hline S. magnolia & Migratory & Summer & 2 & $25.6 \pm 0.27$ & $4.8 \pm 0.2$ & $52.12 \pm 0.45$ \\
\hline S. pensylvanica & Migratory & Summer & 2 & $26.21 \pm 1.01$ & $3.85 \pm 0.25$ & $49.75 \pm 2.44$ \\
\hline S. petechia & Migratory & Summer & 5 & $26.2 \pm 0.59$ & $4.68 \pm 0.12$ & $49.23 \pm 0.7$ \\
\hline S. pinus & Partial migrant & Summer & 4 & $27.29 \pm 1.18$ & $7.3 \pm 0.32$ & $58.87 \pm 0.88$ \\
\hline Sialia mexicana & Partial migrant & Summer & 9 & $31.51 \pm 0.47$ & $16.48 \pm 0.33$ & $74.84 \pm 0.6$ \\
\hline S. sialis & Partial migrant & Summer & 9 & $31.32 \pm 0.6$ & $15.87 \pm 0.46$ & $70.34 \pm 0.96$ \\
\hline Sitta carolinensis & Sedentary & Summer & 3 & $25.11 \pm 0.43$ & $6.83 \pm 0.27$ & $52.36 \pm 0.85$ \\
\hline Spinus pinus & Migratory & Summer & 3 & $25.01 \pm 1.07$ & $5.93 \pm 0.22$ & $51.37 \pm 1.24$ \\
\hline S. psaltria & Migratory & Stopover & 5 & $23.38 \pm 0.62$ & $4.68 \pm 0.12$ & $45.99 \pm 1.04$ \\
\hline S. tristis & Migratory & Summer & 7 & $25.49 \pm 0.46$ & $6.34 \pm 0.19$ & $53.26 \pm 0.8$ \\
\hline Spizella breweri & Migratory & Summer & 5 & $30.53 \pm 0.77$ & $7.52 \pm 0.39$ & $62.53 \pm 0.98$ \\
\hline S. passerina & Migratory & Summer & 5 & $29.99 \pm 0.46$ & $8 \pm 0.44$ & $63.1 \pm 1.99$ \\
\hline S. pusilla & Partial migrant & Summer & 7 & $30.09 \pm 0.6$ & $8.13 \pm 0.25$ & $66.08 \pm 0.84$ \\
\hline Sporophila torqueola & Sedentary & Summer & 6 & $23.34 \pm 0.86$ & $4.15 \pm 0.16$ & $44.87 \pm 1.02$ \\
\hline Toxostoma rufum & Migratory & Summer & 7 & $41.26 \pm 1.2$ & $38.96 \pm 0.7$ & $109.81 \pm 1.2$ \\
\hline Turdus migratorius & Migratory & Summer & 7 & $44.4 \pm 1.38$ & $43.57 \pm 1.47$ & $105.84 \pm 1.19$ \\
\hline Vermivora cyanoptera & Migratory & Summer & 3 & $25.46 \pm 0.43$ & $3.63 \pm 0.18$ & $47.21 \pm 0.93$ \\
\hline Vireo griseus & Migratory & Summer & 8 & $24.73 \pm 0.46$ & $3.61 \pm 0.17$ & $50.16 \pm 0.67$ \\
\hline V. huttoni & Sedentary & Summer & 2 & $22.24 \pm 0.15$ & $4.55 \pm 0.05$ & $54.85 \pm 0.15$ \\
\hline V. olivaceus & Migratory & Summer & 6 & $27.92 \pm 0.4$ & $6.55 \pm 0.13$ & $57.72 \pm 0.68$ \\
\hline Zonotrichia albicollis & Migratory & Summer & 7 & $33.31 \pm 0.91$ & $12.73 \pm 0.31$ & $76 \pm 0.85$ \\
\hline Z. atricapilla & Migratory & Summer & 7 & $35.79 \pm 0.64$ & $16.81 \pm 0.59$ & $79.69 \pm 1.38$ \\
\hline Z. leucophrys & Partial migrant & Summer & 7 & $32.71 \pm 0.64$ & $13.41 \pm 0.38$ & $73.04 \pm 0.67$ \\
\hline
\end{tabular}

